\title{
ANALYSIS OF OPTIMAL RAW MATERIAL INVENTORY NEEDS IN SMALL AND MEDIUM INDUSTRIES (STUDY ON NADYA FURNITURE IN AMBON CITY)
}

\author{
La Irsan ${ }^{1}$, Jusuf Sahupala ${ }^{2}$, Tina D. Kaisupy ${ }^{3}$ \\ ${ }^{1,2,3}$ Universitas Darussalam, Jl. Waehakila Puncak Wara, Ambon, Indonesia \\ Email: lairsan.unidar@gmail.com
}

\section{Article History}

Received: 12-02-2020

Revision: 26-05-2020

Accepted: 04-09-2020

Published: 05-09-2020

\begin{abstract}
The purpose of this research is to determine the need for optimal raw material supplies at Nadya Furniture in Ambon City for a certain period of time, so that there is no delay in raw materials and production targets are set to be achieved. This type of research is qualitative research. The data sources used in this study are primary and secondary data. Data analysis tools used are demand forecasting with time series method and Material Requirement Planning (MRP). The results showed that the optimal order amount for ironwood was 96 meters for January and 396 meters for February, for linggua wood was 1,568 meters for January and 2,616 meters for February, and Linggua Board was 420 meters for January and 920 meters for February 2020. inventory costs for each raw material namely Ironwood Rp. 3,139,744, Linggua Wood Rp. 3,420,016, Hensel cabinet Rp. 2.603.920, House lock Rp. 1.965.768, cupboard handle Rp. 1.965.760, Mirror Rp. 1.765.600, Hensel door Rp. 1.673.400 and Door handle Rp. 2.874.528.
\end{abstract}

Keywords: Raw Material Supply, Material Requirement Planning (MRP)

\begin{abstract}
Abstrak. Tujuan penelitan ini adalah menetukan kebutuhan persediaan bahan baku yang optimal pada Mebel Nadya di Kota Ambon untuk jangka waktu tertentu, sehingga tidak ada keterlambatan bahan baku dan target produksi yang ditetapkan dapat tercapai. Jenis penelitian ini adalah penelitian kualitatif. Sumber data yang digunakan dalam penelitian ini adalah data primer dan sekunder. Alat analisis data yang digunakan adalah peramalan permintaan dengan metode time series dan Material Requirement Planning (MRP). Hasil analisis menunjukkan bahwa besarnya jumlah pesanan optimal untuk kayu besi adalah 96 meter untuk Bulan Januari dan 396 meter untuk Bulan Februari, untuk kayu linggua adalah 1.568 meter untuk Bulan Januari dan 2.616 meter untuk Bulan Februari, dan Papan linggua adalah 420 meter untuk Bulan Januari dan 920 meter untuk Bulan Februari 2020. biaya persediaan untuk setiap bahan baku yaitu Kayu besi Rp. 3.139.744, Kayu linggua Rp. 3.420.016, Hensel lemari Rp. 2.603.920, Rumah kunci Rp. 1.965.768, gagang lemari Rp. 1.965.760, Cermin Rp. 1.765.600, Hensel pintu Rp. 1.673.400 dan Gagang pintu Rp. 2.874.528.
\end{abstract}

Kata Kunci: Persediaan Bahan Baku, Material Requirement Planning (MRP)

How to Cite: Irsan, L., Sahupala, J., \& Kaisupy, T. D. (2020). Analysis of Optimal Raw Material Inventory Needs in Small and Medium Industries (Study on Nadya Furniture in Ambon City). Indo-Fintech Intellectuals: Journal of Economics and Business, 1 (1), 32-39. http://doi.org/10.54373/ifijeb.v1i1.13 


\section{INTRODUCTION}

Intense competition between manufacturers, especially those producing the same goods, encourages companies to be able to compete with having a competitive advantage, especially in meeting customer demand or providing services to customers. Meeting customer needs indirectly affects customer loyalty and corporate profit (Selang, 2013). If customer demand is not met, then the company will lose its current profit and future profit due to the loss of customers. Demand by customers that occurs volatilely becomes one of the problems that must be faced by the company.

Uncertainty in the amount and time of customer demand encourages inventory this is caused by four factors of the function of inventory, namely time factor, discounting factor, indy factor, and economic factor (Rika, 2009). Time factors include processes of production and distribution that take a relatively long time, discounting factors allow treatment of a wide range of different operations, such as retail operations, distribution, warehousing, production, and purchase. An inde determinable factor is the focus on unexpected events that can change the original schedule that has been planned. Economic factors allow companies to benefit from a variety of cost-reduction alternatives.

Raw materials are one of the most important production factors. Lack of available raw materials can result in a halt in the production process due to the depleted materials for processing (Andriani, 2017). However, oversupply of raw materials can result in too high cost burdens to store and maintain such materials during storage in warehouses. The condition of over stock is reviewed financially or spending is not effective because of the large amount of capital goods that are idle and do not rotate. Therefore, although it is reviewed in terms of the smoothness of the over stock state process it can mean positive but reviewed in other respects, especially in terms of cost can have negative consequences in the sense of high costs that must be borne (Sukanto, 2000).

The continuity of a company's production process will not be disrupted if the company is able to control the supply of raw materials. Control over raw material inventory will affect inventory costs and will affect the profits that will be received by the company. The purpose of raw material control is to try to provide the necessary raw materials for the production process so that the production process can run smoothly there is no shortage of inventory (out of stock) and obtained minimal inventory costs (Sukanto, 2000).

Nadya Furniture is one of the companies in the Maluku region that produces a variety of furniture products. One to maintain the continuity of the company, Nadya Furniture must be able to maintain the quality of the product of course by optimizing the number of orders 
tailored to the needs of raw materials. Consumer demand that suddenly requires company owners to avoid delays in delivery of orders and stacking of raw materials in warehouses that cause the production process of Nadya Furniture to decrease the company's profits. The raw materials needed in this furniture production still come from the Seram islands and maluku islands with various types of rich namely: linggua and teak wood and some other wood.

Along with the urgent need for efficiency and effectiveness efforts, a inventory control over the supply of raw materials as one of the inputs or inputs of the production process becomes important to note. Because if a component inventory does not exist when needed, it will cause a cessation of production process. Furthermore, it will be fatal for the company (Riyanto, 2017). Nadya Furniture is one of the companies that often have problems with raw materials. The lack of supply of raw materials in warehouses and there are always delays from suppliers from the regions where the raw materials are ordering and the lack of supplies obtained so that there is a shortage of inventory in the warehouse.

\section{METHOD}

This research uses quantitative method, which is a research procedure that produces descriptive data in the form of written or oral data from the observed people, namely research that aims to obtain data and information on determining the needs of optimal raw material supplies in small and medium industries in nadya furniture in ambon city. Sampling method using Convenience Sampling is a convenient sampling done by choosing a free sample at the researcher's will (Jogiyanto, 2009). The samples used in this study were types of ironwood, linggua wood and linggua boards that were ordered within a period of up to 1 month.

According to (Schroeder, 1995), inventory is a stock of materials used to facilitate production or to satisfy customer demand. Some authors define preparations as an idle resource of various types that have potential economic value. This definition allows one to regard equipment or unemployed workers as preparations, but we consider all unemployed resources other than materials as capacity. Kumar (2008) states that Materials Requirement Planning (MRP) is a technique to determine the quantity and time for the purchase of dependent request items needed to meet the needs of the Master Production Schedule. Meanwhile (Haizer et al., 2015) defines Materials Requirement Planning (MRP) as a bound demand technique that uses a list of material needs, inventory, estimated receipts, and master production schedules to determine material needs. (Haizer et al., 2015) states that the MRP system is an excellent way to determine production schedules and net needs. However, when 
there is a net need, then a decision on how much to order must be made. This decision is called lot-sizing decision.

Demand for product components can be calculated based on the demand of the finished product which is based on customer demand forecasting. Some inputs from the MRP system consist of master production schedule, product structure, material needs list, lead time data, inventory records. In addition, an optimal lot measuring analysis is also carried out as the proposed raw material inventory system. The conceptual framework of this research can be described as follows.

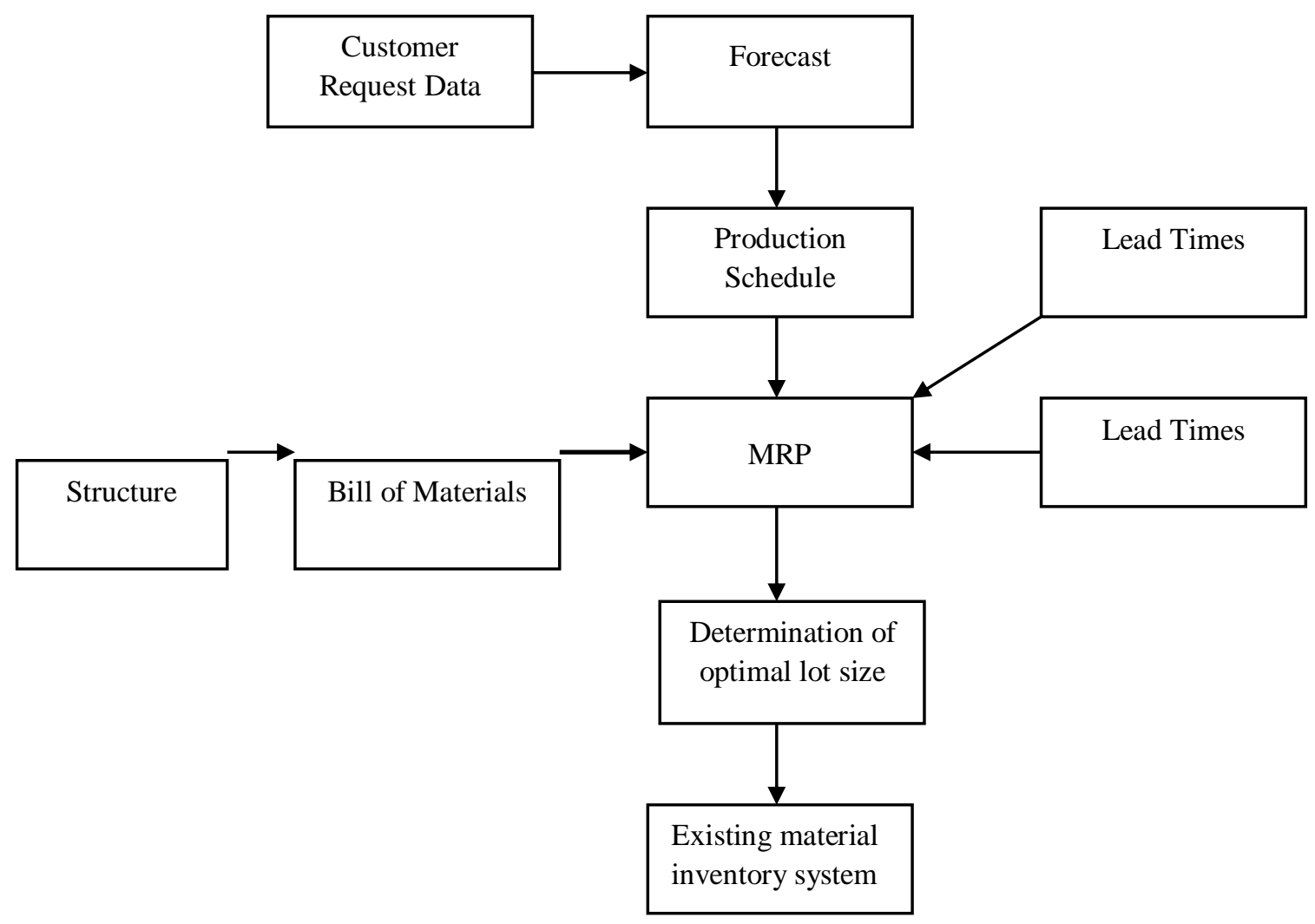

Figure 1. Conceptual Framework

\section{RESULTS}

Requests for products of sills, cabinets, chairs, tables and doors occur randomly. According to Lindawati (Irwansyah, 2010), forecasting methods that can be used for random requests are Moving Average and Single Exponential Smoothing. Demand forecasting results with POM for Windows 3 show that january and February demand forecasting results with the Single Exponential Smoothing method are better than the Moving Average method, as they have smaller MAD, MAPE, and MSE (Rangkuti, 2015). The results of forecasting the demand for products frames, cabinets, chairs, tables and doors are presented in the following table. 
Table 1. Forecasting Demand for Products Frames, Cabinets, Chairs, Tables, and Doors in January and February 2020

\begin{tabular}{lccccc}
\hline Months & Frame & Cabinets & Chair & Desk & Door \\
\hline January & 33 & 6 & 122 & 122 & 27 \\
February & 33 & 6 & 124 & 124 & 27 \\
\hline
\end{tabular}

Analysis of Material Requirement Planning in the research was done manually, because the number of items seen in production is relatively small. Material Requirement Planning has four main steps, the next four steps are applied one by one (Prawisentono \& Suryadi, 2017). The steps are as follows:

a) Offsetting, shows that the procurement process of Nadya Furniture products starting from the procurement of raw materials to complete the product is for three weeks, namely from the 1 st week to the 4th week and the 4th week to the 7th week. So, in the 4th week of January, when the product has been completed, it is also done ordering raw materials to meet the procurement of products for February. Product demand for February can be completed in the 7 th or 3rd week of February.

b) Neeting Netting process is carried out based on Master Production Schedule of Frame products, cabinets, chairs, tables and doors for January and February of 2020. Calculation of net sills, gross needs of 66 and net needs of 66. Calculation of clean cabinets, gross needs 12 and net needs 12, Calculation of clean seats, gross needs of 246 and net needs of 246. Calculation of net table, gross needs 246 and net needs 246. Calculation of clean doors, gross needs of 54 and net needs of 54.

c) Explosion is the process of calculating the gross needs for the level of items or components further down. This calculation of gross needs is based on the plan of ordering product items at a higher level. Gross needs can be determined by calculating the Bill of Material for January and February of 2020 based on master production schedule and bill of material products, cabinets, chairs, tables and doors.

d) Lotting is the process to determine the optimal order size for each product item based on the results of the calculation of net needs. Determination of the optimal amount of order is only done on raw materials or components ordered, namely ironwood, linggua wood, and linggua boards. The calculation of optimal orders is not done for sills, cabinets, chairs, tables and doors, because the amount produced is in accordance with the provisions of a set of Nadya Furniture products. 


\section{DISCUSSION}

Material Requirement Planning analysis on Nadya Furniture is done manually, because the number of items seen in production is relatively small. Based on The Bill of Materials and Time-Conditioned Product Structure for seven periods in January and February 2020, ordering, production process and final product completion can be determined with the following details: (1) Ironwood, linggua wood, boards, hensel cabinets, lock houses, cabinet handles, mirrors, door handles and door handles ordered in the 1st week of January (period 1) and the 4th week of January (period 4), so it can be available in warehouses on the 2nd week of January (period 2) and the 1st week of February (period 5). (2) The making of kuseng, cabinets, chairs, tables and doors begins in the 2nd week of March (period 2) and the 1st week of February (period 5 and ready to be done the finishing process in the 3rd week of January (period 3) and the 2nd week of January (period 6). (3) 33 frames, 6 cabinets, 122 and 124 seats, 122 and 124 tables and 27 doors were completed in the 4th week of January (period 4) and the 3rd week of February (period 7).

Analysis of lot size with Lot for Lot and Part Period Balancing (PPB) techniques has been done, then determine the technique that has the minimum total inventory cost, then it can be known the optimal lot size for each raw material. Thus, each raw material does not have to have the same technique and provides an overview of the total inventory cost comparison for both techniques for each raw material. To determine the lot sizing for ironwood, linggua wood and linggua boards that produce optimal lot size is Part Period Balancing (PPB) technique, because it has a total inventory cost that is smaller than the Lot for Lot technique. As for hensel cabinets, house locks, cabinet handles, mirrors, door handles and door handles, lot sizing lot techniques lot for Lot for Lot and Part Period Balancing (PPB) produce the same total inventory cost. In this state, one of the lot sizing techniques can be selected. However, in this study the technique chosen was Part Period Balancing (PPB), because to consider the purchase quantity that can balance the cost of ordering and storage costs based on the cumulative net needs of some periods combined.

Lot Sizing technique chosen is not the standard reference for Nadya Furniture. This is because in determining the optimal lot size for each raw material is influenced by the amount of raw material needs, ordering costs, and storage costs for each raw material that can change. So, it is necessary to recalculate the optimal lot size, especially in case of changes in order costs and storage costs of each raw material to get an accurate calculation. 


\section{CONSLUSION}

Material Requirement Planning analysis on Nadya Furniture is done manually, because the number of items seen in production is relatively small. Based on the Bill of Materials and Time-Conditioned Product Structure for seven periods in January and February 2020, it can be determined that the ordering of raw materials, the production process until the completion of the final product.

The optimal order amount for ironwood was 44 pieces for January and 132 pieces for February, for linggua wood was 211 pieces for January and 620 pieces for February, and Linggua Board was 373 sheets for January and 5510 pieces for February 2020. The amount of inventory cost for each raw material is: Ironwood Rp. 20.989.120, Kayu linggua Rp. 31.313.910. Hensel cabinets Rp. 40.749.230. House lock Rp. 1.965.768. Cupboard handle Rp.1.965.760. Mirror Rp. 1.765.600. Hensel door Rp. 1.673.400. Doorknob Rp. 2.874.528.

\section{RECOMMENDATIONS}

Lot Sizing technique chosen is not the standard reference for Nadya Furniture. This is because in determining the optimal lot size for each raw material is influenced by the amount of raw material needs, ordering costs, and storage costs for each raw material that can change. So, it is necessary to recalculate the optimal lot size, especially in case of changes in the ordering cost and storage cost of each raw material to get an accurate calculation.

Preferably in determining the company's lot sizing using ppb approach because this method considers the quantity of purchases that can balance the cost of ordering and storage costs based on the cumulative net needs of several periods combined. Companies can establish optimum safety inventory policies to avoid delays and run out of materials, especially for purchased raw materials.

\section{REFERECES}

Andriani, D. N. (2017). Pengaruh modal, tenaga kerja, dan bahan baku terhadap hasil produksi (studi kasus pabrik sepatu PT. Kharisma Baru Indonesia). EQUILIBRIUM: Jurnal Ilmiah Ekonomi Dan Pembelajarannya, 5(2), 151-162.

Haizer, Jay, \& Render, B. (2015). Operations Management (Kesembilan). Salemba empat. Irwansyah, D. E. (2010). Penerapan Material Requirements Planning (MRP) dalam Perencanaan Persediaan Bahan Baku Jamu Sehat Perkasa pada PT. Nyonya Meneer. http://eprints.undip.ac.id/19378/1/skripsi.pdf [29 Juni 2012]

Jogiyanto. (2009). Sistem Informasi Manajemen. Andi.

Kumar. (2008). Production and Operations Management: with Skill Development, Caselets, and Cases. New Age International (P) Limited. 
Prawisentono, \& Suryadi. (2017). Manajemen Operasi: Analisis dan Studi Kasus (Ketiga). Bumi Aksara.

Rangkuti. (2015). Manajemen Persediaan Aplikasi di Bidang Bisnis. Erlangga.

Rika, A. (2009). Manajemen pabrik: pendekatan system untuk efesiensi dan efektifitas. Jakarta: Bumi Aksara.

Riyanto, B. (2017). Dasar-dasar Pembelajaran Perusahaan (keempat). BPFE.

Schroeder. (1995). Pengambilan Keputusan Dalam Suatu Fungsi Operasi (Ketiga). Erlangga.

Selang, C. A. D. (2013). Bauran pemasaran (marketing mix) pengaruhnya terhadap loyalitas konsumen pada fresh mart Bahu Mall Manado. Jurnal EMBA: Jurnal Riset Ekonomi, Manajemen, Bisnis Dan Akuntansi, 1(3).

Sukanto. (2000). Manajemen Produksi. BPFE UGM. 